\title{
International Journal of Contemporary Tourism Research
}

http://dergipark.gov.tr/ijctr

\section{PAKET YEMEK SİPARIŞLERINDE ÇEVRIMIÇİ ARACI KULLANAN TÜKETICİ DAVRANIŞLARININ GENIŞLETILMIŞ TEKNOLOJI KABUL MODELIYLE ARAŞTIRILMASI}

Araştırma Makalesi

Miray KILIÇALP ${ }^{1}$, Osman Nuri ÖZDOĞAN ${ }^{2}$

ÖZET

Bu çalışmada, çevrimiçi paket servis portallarını aktif olarak kullanmakta olan tüketicilerin çevrimiçi yemek siparişine ilişkin tutum ve davranışlarını etkileyen faktörlerin genişletilmiş teknoloji kabul modeli ölçeği ve eAlışveriş Kalitesi ölçeği yardımıyla incelenmesi amaçlanmıştır. Bu amaçla, oluşturulan anket formu, çevrimiçi olarak anket hazırlama ve toplama hizmeti sunan bir web sitesi aracılılığıyla sosyal medya ve mail hesapları üzerinden link paylaşımı ile katılımcılara ulaştırılmıştır. Gerçekleştirilen analizler sonucunda e-alışveriş kalitesi ile algılanan kullanışlılık ve algılanan kullanım kolaylığı, algılanan kullanışlılık ile kullanıma dönük tutum ve kullanıma dönük niyet, kullanıma dönük tutum ile kullanıma dönük niyet kullanıma dönük niyet ile öznel normlar ve gerçek sistem kullanımı boyutları arasında pozitif yönlü ilişkiler olduğu görülmüştür.

Anahtar Sözcükler: e-ticaret, e-tüketici, çevrimiçi yemek siparişi, e-alışveriş kalitesi, genişletilmiş Teknoloji Kabul Modeli

JEL Sinıflandırma Kodu: L83

\section{INVESTIGATING OF CONSUMERS' BEHAVIORS USING ONLINE FOOD DELIVERY SERVICES IN PACKED FOOD ORDERS BY EXTENDED TECHNOLOGY ACCEPTANCE MODEL}

\section{Research Article}

\begin{abstract}
In this study, it is aimed to investigate the factors that affect the attitude and behaviors of consumers who are using online packed service portals actively with the help of expanded technology acceptance model and eshopping quality scale. For this purpose, the questionnaire form was sent to the participants via a web site that provides online survey preparation and collection services. According to analysis results, it was seen that there were positive relations between e-shopping quality and perceived usefulness and perceived ease of use, perceived usefulness and attitude towards use and intention to use, attitude towards use and intent to use, intentional towards use, subjective norms and actual system use dimensions.
\end{abstract}

Keywords: e-commerce, e-consumer, online food ordering, e-shopping quality, extended Technology Acceptance Model

JEL Classification Code: L83

\footnotetext{
1 Dr., Aydın Adnan Menderes Üniversitesi, Sosyal Bilimler Enstitüsü, Turizm İşletmeciliği Anabilim Dalı, mryonal@gmail.com,orcid.org/0000-0002-5200-9256

2 Prof. Dr., Aydın Adnan Menderes Üniversitesi, Turizm Fakültesi, Konaklama İşletmeciliği Bölümü, onozdogan@gmail.com,orcid.org/0000-0002-8624-5206

"Kılıçalp M., Özdoğan O. N. (2019). Paket Yemek Siparişlerinde Çevrimiçi Aracı Kullanan Tüketici Davranışlarının Genişletilmiş Teknoloji Kabul Modeliyle Araştırılması, International Journal of Contemporary Tourism Research, Vol 3: No: 2, p.148-163, doi: 10.30625/ijctr.618952" 


\section{GíRiş}

Elektronik ticaret alanında yaşanan gelişmelere paralel olarak internet üzerinden yapılan alışverişin artması ile birlikte işletmeler e-ticarete yönelmişler ve ișletmelerin tüketiciye ulaşmak için kullandıkları aracılar ortadan kalkmıștır. Bununla birlikte e-ticaret faaliyetlerine artan bu olağanüstü ilgi karşısında, elektronik ortamda işletmeler ve tüketiciler arasında aracılık görevi üstelenen yeni çevrimiçi aracı işletmeler de ortaya çıkmıştır. Paket yemek servis hizmeti sağlayan ve yiyecek içecek işletmeleri tarafından kullanılan, internet üzerinden hizmet veren yemek sipariş siteleri de söz konusu çevrimiçi aracı işletmelere örnek teşkil etmektedir.

İnternet üzerinden hizmet veren çevrimiçi aracı yemek sipariş siteleri tüketicilere farklı mutfaklardan diledikleri yiyecek ve içecekleri seçip sipariş vermelerine, ülke genelinde ve bulundukları bölgeye ait promosyon ve indirimlerden yararlanmalarına, satın alma sonrasında da servis kalitesi, hiz ve yiyecek kalitesini puan vererek satın aldıkları ürün ve hizmeti derecelendirmelerine olanak sağlamaktadır.

E-ticaret kapsamında faaliyet gösteren çevrimiçi aracilardan biri de fastfood, restoran, kafe gibi yiyecek ve içecek işletmelerinden yemek siparişini elektronik ortamda vermeye imkan sunan, işletmelerle müşterileri bir araya getiren çevrimiçi yemek sipariş sistemi olarak adlandırılan internet siteleridir. Üye işletmelerden bağımsız olarak çalışan, işletmelerin ürünlerini doğru yere, zamanında, eksiksiz ve müşteri beklentilerine uygun bir şekilde teslim edilmesini sağlayan ve bu süreçte oluşan problemlerin çözümünde stratejik rol oynayan bu sistem ve e-aracilar paket servis müşterileri tarafindan her geçen gün daha fazla benimsenmektedir (Tomaş, 2014: 30).

İnternet kullanımının yaygınlaşması ile birlikte Türkiye'de ki paket yemek servis siparişlerinde çevrimiçi kanalların kullanımı da artmakta ve yaygınlaşmaktır. $\mathrm{Bu}$ durum pazarı oldukça cezbedici bir konuma getirmiştir. Çevrimiçi paket servis sistemini çevrimiçi aracı portallardan bağımsız bir şekilde kendi internet sitelerine ekleyen ulusal çapta faaliyet gösteren restoran işletmeleri ile uluslararası restoran zincirleri de çevrimiçi paket yemek servis siparişi verme imkanı sunmaktadırlar. Bununla birlikte pazarda çevrimiçi aracı olarak hizmet sunan birçok internet sitesi de faaliyet göstermektedir (yemeksepeti.com, yemekmotoru.com, adreseyemek.com, neyiyelim.com, yemekx.com, uniyemek.com, vd.).

2001 yılında Nevzat Aydın tarafından kurulmuş olan ve yüzde 99'luk pazar payı ile Türkiye'nin ilk ve en büyük çevrimiçi paket servis portalı yemeksepeti.com, yerel yiyecek işletmeleri ile birlikte zincir yiyecek içecek işletmelerini tüketici ile buluşturan bir kuruluştur. Portal tüketicilere farklı mutfaklardan diledikleri yiyecek ve içecekleri seçip sipariş vermelerine, ülke genelinde ve bulundukları bölgeye ait promosyon ve indirimlerden yararlanmalarına, satın alma sonrasinda da servis kalitesi, hiz ve yiyecek kalitesini puan vererek satın aldıkları ürün ve hizmeti derecelendirmelerine olanak sağlamaktadır.

2015 yılında Türkiye internet sektörünün en büyük firmalarından olan ve aynı zamanda çevrimiçi yemek sipariș alanında pazar devi olan yemeksepeti.com, Berlin merkezli global çevrimiçi yemek siparis platformu Delivery Hero tarafindan 589 milyon dolara satın alınmıştır. Gerçekleșen bu satın alma Türkiye'de internet sektörünün en büyük satın alması ve ilk 1 milyar TL üzerindeki satış olması nedeniyle oldukça büyük bir yankı uyandırmıştır.

Türkiye'de ilk kez yemeksepeti.com ile başlayan çevrimiçi yemek siparişi uygulaması elde ettiği başarı skalasıyla aradan geçen 18 yıl içinde yeni girişimcilerle yeni bir sektör halini almıştır. yemeksepeti.com sayesinde çevrimiçi yemek sipariş pazarının giderek büyüyerek yaygınlaşması ile pazara her geçen gün yeni oyuncular girmeye başlamıştır (neyiyelim.com, neyemekyesem.com, istelezzet.com, adreseyemek.com, vb. ).

Türkiye'de çevrimiçi yemek siparişi pazarından bahsedildiğinde değinilmesi gereken bir diğer yeni iş modeli ise yemeksepeti'nin son dönemdeki en geniş kapsamlı iş geliştirme projelerinden Yemeksepeti Vale uygulamasıdır. Dünyada ilk kez uygulanan bir model olan yemeksepeti Vale, iş modelleri, operasyonel verimlilik, hizmet kalitesi gibi kaygıları nedeniyle paket servise girmeyi tercih etmeyen işletmelerin, halihazırda bu hizmeti veren deneyimli restoranların kuryelerini kullanmalarına imkan tanımaktadır. Böylece restoranlar kendi uzmanlıkları dışındaki bir işe yatırım yapmak zorunda kalmadan, kullanıc1 
memnuniyeti ve operasyon anlaminda yemeksepeti'nin desteğinden faydalanmaktadırlar. İş Geliştirme Direktörü Mert Baki'nin verdiği bilgiye göre, Yemeksepeti Vale'ye dahil olan restoranlar cirolarını ortalama yüzde 25 oranında büyütmektedir. Kuryelerini diğer restoranların hizmetine sunan restoranlar ise, hem birden fazla paydaş için değer yaratmış olmakta hem de halihazırdaki kuryelerinin boş vakitlerinde ekstra kazanç elde etmektedirler. Bu model, restoranların birbirlerinin kuryelerini kullanmaları itibarıyla, dünyada türünün ilk örneği olarak da öne çıkmaktadır (yemeksepeti.com, 2016).

Değişen toplum yapısı beraberinde yeme-içme kültürünün değişmesine de sebep olmuştur. Bütün dünyada olduğu gibi ülkemizde de hızlı yaşayan, gün içinde birçok şeyi yapmak zorunda kalan bireyler yemeği de hizlı yemekte, bu sebeple fastfood zincirlerine talep artmaktadır. Ülkemizde fastfood yemek zincirleri çevrimiçi alışverişte önemli yer kaplamaktadır. Sabah erkenden evden çıkan, öğle yemeğine iş arasında belli bir süre ayıran, akşam eve yorgun gelen insanlar için birkaç tuşa basarak yemek sipariş etmek büyük kolaylıktır. Ülkemizde büyük bir kesimi oluşturan genç nesil yemek yapmayı bilmemekte, ögrenmemekte veyahut yapmak istememektedir. Değişen düzende kadınların çalışma hayatında yer alması bunun en önemli sebeplerindendir (Ar1 ve Y1lmaz, 2015: 66).

\section{LITERATÜR ARAŞTIRMASI}

'We are social' web sitesinin 2018 Dijital Raporuna göre dünya genelinde aktif internet kullanıcı sayısı yaklaşık olarak 4 milyar kişidir. Yaklaşık olarak 82 milyon nüfusa sahip olan Türkiye'de ise bu rakam aktif internet kullanıcı sayısı 54.33 milyon kişi olarak karşımıza çıkmaktadır. $\mathrm{Bu}$ rakam yaklaşık olarak toplam nüfusun \%67'sinin internet bağlantısına sahip olduğunu göstermektedir. Söz konusu raporda kullanıciların elektronik ticaret kapsamında gerçekleştirdiği faaliyetlere ilişkin veriler şu şekildedir;

- İnternet kullanıcıların \%56's1 son 30 gün içerisinde bir mal veya hizmeti satın alma amacı ile arama yapmıştır.

- İnternet kullanıciların \%60'1 son 30 gün içerisinde çevrimiçi bir mağazayı ziyaret etmiştir.

- İnternet kullanıcıların \%43'ü son 30 gün içerisinde çevrimiçi olarak bir ürün veya hizmet satın almıştır.

- İnternet kullanıcıların \%30’u çevrimiçi satın alma işlemini masaüstü veya dizüstü bilgisayar aracılığıyla gerçekleştirmiştir.

- İnternet kullanıcıların \%30’u çevrimiçi satın alma işlemini mobil cihazlar aracılığıyla gerçekleştirmiştir.

Tüketicilerin çevrimiçi olarak gerçekleştirdikleri satın alma işlemlerine ait kategoriler ve toplam harcama tutarları ise su şekildedir;

Tablo 1. Çevrimiçi Satın Alma İşlemlerine Ait Kategoriler ve Harcama Tutarları

\begin{tabular}{|c|c|c|c|}
\hline $\begin{array}{l}\text { Moda ve Güzellik } \\
1.260 \text { milyar } \$\end{array}$ & $\begin{array}{l}\text { Elektronik ve fiziki medya araçları } \\
2.182 \text { milyar } \$\end{array}$ & $\begin{array}{l}\begin{array}{l}\text { Yiyecek ve kişisel } \\
\text { bakım }\end{array} \\
0.410 \text { milyar } \$\end{array}$ & $\begin{array}{l}\text { Mobilya } \\
1.039 \text { milyar \$ }\end{array}$ \\
\hline Oyuncak ve hobi & Seyahat ve konaklama & Dijital Müzik & Video oyunları \\
\hline 0.848 milyar $\$$ & 1.823 milyar $\$$ & 0.026 milyar $\$$ & 0.276 milyar $\$$ \\
\hline
\end{tabular}

Türkiye'de 2085 tüketicinin katılımıla gerçekleştirilen bir çalışmaya göre, e-ticaret kullanıcıları en çok giyim, elektronik, yemek siparişi, seyahat/konaklama ve kitap kategorilerinde işlem gerçekleştirmektedir (TUSİAD, 2019: 18).
Ticaret kar amacı güdülerek gerçekleştirilen alım satım faaliyetlerin tümünü kapsayan bir kavramdır. Ticaretin gerçekleşebilmesi için satıcı ve alıcıların buluşacağı ve alım satım işlemlerinin gerçekleştirilebileceği bir satış yerine ihtiyaç vardır. $\mathrm{Bu}$ satış yeri dükkân, mağaza, depo gibi 
fiziki bir yer olabileceği gibi, internet ağları üzerinden işlem gerçekleştirilebilen sanal mağazalar şeklinde de olabilmektedir. Günümüzde hizla arttan e-ticaret ise genellikle internet, intranet ve extranet gibi iletişim ağları aracılığıyla ürün, hizmet ve bilgi alış, satış veya alışverişi dahil olmak üzere ticari işlemlerin yapılmasının yeni bir yolunu ifade etmektedir (Dou ve Chou, 2002: 165).

Dünya Ticaret Örgütünün tanıma göre e-ticaret: Mal ve hizmetlerin üretim, reklam, satış ve dağıtımlarının telekomünikasyon ağları üzerinden gerçekleştirilmesidir (WTO, 2016). Genel bir ifade ile e-ticaret, alıcılar ve satıcılar arasında para, ürün veya hizmetlerin değişiminin internet teknolojilerinin kullanılarak yapılmasıdır. Literatürde bazı kaynaklarda e-ticaret kavramı tanımı için tüm elektronik vasıtaları içerecek şekilde bir tanım yapıldığı görülmektedir.

Elektronik ticaret değişik kişi ve gruplar arasında yapılabilmektedir. Elektronik ticarette tarafları esas alan bir sinıflandırma yapıldığında e-ticaret faaliyeti, "İşletmeden İşletmeye (B2B), İşletmeden Tüketiciye (B2C), Tüketiciden-Tüketiciye (C2C) ve İşletmeden Devlete (B2G) e-ticaret olmak üzere dört ana gruba ayrilabilir (Erbaşlar ve Dokur, 2012: 33). Bu çalışmada ele alınan konu işletme ile tüketici arasında gerçekleştirilen eticaret grubu kapsamındadır.

E-Tüketici ise, elektronik sözleşmeler ile mal ve hizmeti temin eden tüketicidir. E-tüketici, tüketici tanımının bir alt kavramı olarak düşünülebilir. Başka bir deyişle, ticari veya mesleki olmayan amaçlarla hareket eden, elektronik iletişim araçlarını kullanarak bir mal veya hizmet edinen, kullanan veya yararlanan gerçek ya da tüzel kişidir (Tiryaki, 2008: 92).

E-tüketiciler genel özellikleri itibariyle eğitim seviyesi yüksek, bilgi donanımına sahip, bilinçli, fazla marka sadakati bulunmayan, istek ve beklentileri karşılanmadığ 1 zaman bir tek tık ile rakibe kaçan, sunulan her servis ve ürünü hemen satın almayan kişi ve kurumlar olarak tanımlanmaktadır (Erçetin, 2015: 13).

E-ticaret kapsamında gerçekleştirilmiş olan geçmiş çalışmalar incelendiğinde teknolojik faktörler, alışveriş faktörleri ve ürün özelliklerinin çevrimiçi satın alma kararında önemli bir etkiye sahip oldukları görülmektedir.
Literatürde çevrimiçi aracılar ile ilgili çalışmaların çoğunlukla tüketiciler açısından ele alındığı görülmektedir (Constantinides, 2004; Chen, vd. 2010; Hong ve Cho 2011; Kimes, 2011b; Alagöz ve Hekimoğlu 2012; Tomaş 2014; Arı ve Yılmaz 2015).

Constantinides (2004) çevrimiçi tüketici davranışını etkileyen faktörler ve web deneyimine ilişkin gerçekleştirmiş olduğu çalışmasında web deneyimlerinin temel taşlarını oluşturan faktörleri şu şekilde sıralamıştır; İşlevsellik faktörleri (kullanılabilirlik ve etkileşim), psikolojik faktörler (güven) ve içerik faktörleri (estetik ve pazarlama karmas1). Vijayasarathy (2004) web sitesi niteliklerinin çevrimiçi satın alma niyetini etkilediğini saptamıştır. Benzer bir şekilde Bai ve arkadaşları (2008) web sitesi kalitesinin müşteri tatmini ve satın alma niyetine olan etkilerini inceledikleri araştırmalarında, web sitesi niteliklerini işlevsellik ve kullanılabilirlik olarak iki ana faktör altında incelemişler ve web sitesi niteliklerinin müşteri tatmini yaratmada etkili olduğunu ve bu durumun çevrimiçi satın alma davranışı ile pozitif bir ilişki içerisinde olduğunu saptamışlardır. Araştırma sonuçlarına göre web sitesi kalitesinin müşteri memnuniyeti üzerinde doğrudan ve olumlu bir etkisi olduğunu saptamışlardır. Ayrıca araştırma sonuçlarına göre memnuniyetin satın alma niyetleri üzerinde doğrudan ve olumlu bir etkisi vardır. Web sitesi kalitesinin satın alma niyetleri üzerindeki etkisi varken, müşteri memnuniyeti bu etkiye önemli ölçüde aracılık etmektedir.

Chen ve arkadaşları (2010) ise çevrimiçi tüketici satın alma isteğini arttıran web sitesi niteliklerini araştırdıkları çalışmalarında çevrimiçi tüketici satın alma niyetini etkileyen faktörleri üç ana başlık altında incelemişlerdir; teknolojik faktörler (Güvenlik, gizlilik, kullanılabilirlik), alışveriş faktörleri (kolaylık, güven, teslimat) ve ürün faktörleri (ürün değeri ve ürün seçeneklerinin özellikleri).

Tomaş (2014) paket servis müşterilerinin sipariş vermede e-aracı kullanma nedenlerini araştırdığ 1 çalışma sonuçlarına göre tüketicilerim çevrimiçi sipariş sistemini tercih nedenleri teknoloji faktörleri, alışveriş faktörleri, ürün faktörleri ve bireysel faktörler olarak sınıflandırılmıştır.

Wolfinbarger ve Gilly, (2003)' de e-alışveriş kalitesi deneyiminin boyutlarını belirlemek ve e- 
alıveriş kalitesinin ölçümünü gerçekleştirebilmek adına güvenilir ve geçerli bir ölçek geliştirmişlerdir. Çalışma sonucunda dört ana boyutun (web sitesi tasarım1, taahhütlerin yerine getirilmesi /site güvenilirliği, gizlilik / güvenlik ve müşteri hizmetleri) müşteri kalite ve memnuniyet konusundaki kararlarını, müşteri sadakatini ve web sitesine yönelik tutumlarını güçlü bir şekilde etkilediğgi saptamışlardır. Ha ve Stoel, (2009)' da aynı ölçekten yararlanarak gerçektirdikleri araştırmada Wolfinbarger ve Gilly, (2003)'den farklı olarak e-alışveriş kalitesinin boyutlarını web sitesi tasarımı, gizlilik / güvenlik, müşteri hizmetleri ve deneyimleme olarak saptamışlardır.

Müşterilerin çevrimiçi alışverişe yönelik tutumlarının, elektronik alışverişin potansiyelini etkileyen ana etmen olduğu bilinmektedir. Müşterilerin tutumlarını anlamak, pazarlama yöneticilerinin çevrimiçi alışveriş oranını belirlemesine ve çevrimiçi ticaretin gelecekteki büyümesini değerlendirmesine yardımcı olur (Algür ve Cengiz, 2011: 3667).

Çevrimiçi yemek sipariş sistemini kullanan restoran işletmeleri üzerinde Kimes ve Laqué, (2011) tarafindan gerçekleştirilmiş olan çalışmada, çevrimiçi yemek sipariş sisteminin olası avantajları ve dezavantajları saptanmıştır. Ayrıca Kimes (2011a) Amerika'da gerçekleştirdiği çalışmada restoran işletmecilerinin çevrimiçi sipariş hakkındaki görüşlerini araştırırak çevrimiçi yemek siparişin mevcut durum analizini gerçekleştirmiştir.

Bozdoğan (2012) e-ticaret kapsaminda yemeksepeti.com üzerinden satış yapan yiyecekiçecek işletmeleri üzerinde gerçekleştirmiş olduğu çalışmasında işletmelerde e-ticaretin güvenliğine yönelik düşünceler ile yemeksepeti.com'un yiyecek-içecek satışını arttırmada önemli bir araç olarak seçilmesi arasında anlamlı bir ilişki bulunduğu saptamış, sitenin işletmeler tarafından yiyecek-içecek satışını artırma amacıyla tercih edildiğini belirlemiştir.

Davis tarafindan 1989 yılında geliştirilen Teknoloji Kabul Modelinin (Technology Acceptance Model, TAM) amacı teknolojinin kullanıcı kabulü, özellikle de bilgisayar teknolojilerini kullanımı davranışını anlamaktır. Davis (1989: 321)' de algılanan kullanışlilık (fayda) ve algılanan kullanım kolaylığını bilgi sistemlerinin kullanımında bireylerin niyetlerini ve tutumlarını etkileyen önemli faktörler olarak tanımlamaktadır.

Son otuz yıl süresince yapılan çalışmalar incelendiğinde TKM'nin internet ile ilgili teknolojilerin kabulünde de kullanılabilecek uygun bir model olduğu görülmektedir. TKM'nin internet tabanlı teknolojilerin kullanımında uygun bir model olarak görülmesinin nedeni, internetin teknolojisinin bilgisayar tabanlı bir bağlantı şekli olması olarak yorumlanabilir. $\mathrm{Bu}$ bağlamda TKM'nin çevrimiçi alışveriş davranışının anlaşılması için kullanılabilecek bir model olduğunu söylenebilir. Bununla birlikte literatür incelendiğinde çevrimiçi alışveriş davranışını anlamaya ilişkin gerçekleştirilen çalışmalarda (Arı ve Y1lmaz, 2015; Alagoz ve Hekimoglu, 2012) TKM'nin tek başına yeterli olmadığı durumlarda ortaya çıkmaktadır.

Davis (1989) tarafından geliştirilmiş olan Teknoloji Kabul Modeli, Ajzen ve Fishbein (1980) tarafindan ortaya konmuş olan Nedenli Eylem Teorisi ile yine Ajzen (1985) tarafindan geliştirilmiş olan Planlı Davranış teorisini baz alarak muhtemel kullanıcıların yeni teknolojileri benimsemelerini açıklamaya ve tahmin etmeye yöneliktir. Teknoloji Kabul Modelinde, teknoloji kullanımına yönelik iki ana faktör olan algılanan kullanım kolaylığı ve algılanan fayda, doğrudan tutumu ve dolaylı olarak davranışsal niyeti açıklamak için kullanılmaktadır.

Planlı davranış teorisi, Ajzen ve Fishbein tarafından 1970'li yıllarda ortaya konan Sebepli Eylem Teorisi (Theory of Reasoned Action)'nin genişletilmiş halidir ve belirli bir bağlamda gerçekleşen insan davranışlarının tahmini ve açıklanması amacıyla tasarlanmış olan bir davranış teorisidir. Genel olarak sosyal psikoloji alanında kullanılmakla beraber, birçok farklı disiplinin alanına giren davranışları açıklama amacıyla da yaygın olarak kullanılmıştır. Planlı davranış teorisinde kişinin davranışının altında yatan niyetlerini etkileyen üç temel faktör bulunmaktadır. Bunlar; davranışa yönelik tutum, öznel normlar ve algılanan davranışsal kontrol algısıdır. Öznel norm, bir kişi için önemli olan veya fikirlerine değer verdiği aile, yakın çevre ve arkadaş çevresinde bulunan insanların o kişi hakkındaki sorularının o kişi tarafından gerçekleştirilip gerçekleştirilemeyeceği konusu hakkında kişinin algısı olarak açıklanmaktadır. 
Öznel norm niyet üzerinde doğrudan bir etkiye sahiptir. Çünkü birey, bir davranış doğrultusundaki tutumu ne olursa olsun, öncelikle kendi referanslarına göre kendi davranışını belirleyecektir. Öznel normun niyet üzerindeki etkisi, genişletilmiş TKM'de önerilmiştir (Davis, 1989: 325). Kişinin referans aldığı görüşleri belirten öznel normlar, ki bu referans alınan kişiler birey için önemli kişi, aile fertleri veya gruplar olabilir, normatif inançlar ve kişinin razı olduğu güdülerden etkilenmektedir.

Alagöz ve Hekimoğlu (2012), Davis (1989) tarafindan geliştirilen Teknoloji Kabul Modeli (TKM) ile üniversite öğrencileri arasında gerçekleştirdikleri çevrimiçi yemek siparişi sistemine karşı tüketicilerin tutumlarını belirlemeye yönelik çalışmalarında, TKM modeline ek olarak e- perakendeciye duyulan güven, yenilikçilik ve diş etkilerin çevrimiçi yemek siparişi veren üniversite öğrencilerinin davranışlarını etkileyen ana faktörler olduğunu saptamışlardır.

Ar1 ve Y1lmaz (2015) üniversite öğrencilerinin çevrimiçi yemek siparişi davranışlarını teknoloji kabul modeliyle araştırdıkları çalışmalarında, Teknoloji Kabul Modeli yardımıyla ortaya koydukları çevrimiçi yemek siparişine ilişkin modelde, algilanan fayda, algilanan kullanım kolaylığının davranışa yönelik tutumu pozitif yönde etkilediği, davranışa yönelik tutum ve kişisel normun ise öğrencilerin çevrimiçi yemek siparişi verme sayısını arttırıcı yönde etkilediği sonucuna varmışlardır.

İnternet kullanımının yaygınlaşması ile birlikte Türkiye'deki paket yemek servis siparişlerinde çevrimiçi kanalların kullanımı da artmakta ve yaygınlaşmaktır. $\mathrm{Bu}$ durum pazarı oldukça cezbedici bir konuma getirmiştir. $\mathrm{Bu}$ çalışmada tüketicilerin çevrimiçi yemek siparişine ilişkin tutum ve davranışları e-alışveriş kalitesi ölçeği ile birlikte genişletilmiş teknoloji kabul modeli yardımıyla açıklanmaya çalışılmıştır.

\section{YÖNTEM}

Çalışmada tüketiciler açısından çevrimiçi yemek sipariş davranışı ve çevrimiçi yemek sipariş sitelerini benimseme durumları öznel norm boyutu da eklenerek genişletilmiş teknoloji kabul modeli ile birlikte e-alışveriş kalitesi ölçeğini de içeren yeni bir model ile incelenmeye çalışılmıştır. Çalışmada kullanılan e-alışveriş kalitesi ölçeğine ait olan ifadeler Wolfinbarger ve Gilly, (2003) tarafından geliştirilmiş olan ve Ha ve Stoel, (2009)'da kullanılmış olan e-TailQ ölçeğinden uyarlanmıştır. genilletilmiş teknoloji kabul modeline ilişkin model ve hipotezlerin belirlenmesinde ise Fischben ve Ajzen (1985) ve Davis (1989) tarafindan geliştirilen teorilerden yararlanılmıştır.

Araştırmanın güvenirliği ve geçerliliğini arttırmak için, anket soruları geçmiş çalışmalardan uyarlanmıştır. Algılanan Kullanışlılık, Algılanan Kullanım Kolaylığı, Davranışa Dönük Tutum, Davranışa Dönük Niyet ve Gerçek Sistem Kullanımı (Davranış) boyutlarında yer alan ifadelerin oluşturulmasında; Ar1 ve Yılmaz, 2015; Akça ve Özer, 2012; Alagoz ve Hekimoglu, 2012; Liang ve Lim, 2011; Turhan ve Özgen, 2009; Turan, 2008; Lam, Cho, ve Qu, 2007; Flavian, Guinalıu, ve Gurrea, 2006; Lai ve Li, 2005; Wu ve Wang, 2005; Chen ve Tan, 2004; Hansen, Jensen ve Solgaard, 2004; Dahlberg, Mallat ve Oorni, 2003; Pavlou, 2003; Suh ve Han, 2002; Shim, Eastlick, Lotz ve Warrington, 2001; Taylor ve Todd, 1995; Davis, Bagozzi ve Warshaw, 1989; Davis, 1989, Fishbein ve Ajzen, 1975 çalışmalardan yararlanılmıştır. Öznel Norm boyutuna ait olan ifadeler, Ar1 ve Y1lmaz, 2015; Liang ve Lim, 2011; Turhan ve Özgen, 2009; Turan, 2008; Lam vd., 2007; Hansen vd., 2004; Shim vd., 2001; Taylor ve Todd, 1995; Fishbein ve Ajzen, 1975'te kullanılmış olan ölçeklerden yararlanarak oluşturulmuştur. e-alışveriş kalitesi ölçeğine ait olan ifadeler Wolfinbarger ve Gilly, (2003) tarafından geliştirilmiş olan ve Ha ve Stoel, (2009)'da kullanılmış olan e-TailQ ölçeğinden uyarlanmıştır.

$\mathrm{Bu}$ araştırmada internet üzerinden hizmet veren yemek sipariş portallarından sipariş vermeyi tercih eden tüketicilerin, çevrimiçi yemek siparişi verme davranışının e-alışveriş kalitesi ölçeği ve genişletilmiş teknoloji kabul modeli kapsamında incelenmesi hedeflenmiştir. $\mathrm{Bu}$ doğrultuda araştırmanın evrenini Türkiye'de ve KKTC de yaşayan ve çevrimiçi aracı hizmeti sağlayan portallara üye olan ve söz konusu hizmet sağlayıcı üzerinden en az bir kere paket yemek servisi satın almış olan tüketicileri oluşturmaktadır. Örnek olarak seçilen \% yüzde 99'luk pazar payı ile Türkiye'nin ilk ve en büyük çevrimiçi hizmet veren paket yemek servis portalına ait kayıtlı üye sayısı 
2018 yılı verilerine yaklaşık olarak 11 milyon kişidir ve yıllık sipariş verilen yemek sayısı 250 milyon porsiyondur. Kayıtlı kullanıcı bilgileri şirket ve sistem tarafindan gizli tutulduğundan, hazırlanmış olan anket formu çevrimiçi olarak anket hazirlama ve toplama hizmeti sunan bir web sitesi aracılılığıyla sosyal medya ve mail hesapları üzerinden link paylaşılması doğrultusunda katılımcılara ulaştırılmıştır ve 1189 geçerli katılımcıya ulaşı1mıştır.

Kullanılan ölçeklerin güvenirliliğini test etmek amacıyla hazırlanmış olan anket formu 1.9.2017 31. 12.2017 tarihleri arasında Tesadüfî örneklem yöntemi ile seçilen 116 yetişkin üzerinde pilot çalışma olarak uygulanmıştır.

Pilot uygulama sonucunda elde edilen veriler doğrultusunda oluşturulan anket formu 01.03.2018 - 01.11.2018 tarihleri arasında çevrimiçi olarak anket hazırlama ve toplama hizmeti sunan bir web sitesi aracılılığıyla sosyal medya ve mail hesapları üzerinden link paylaşılması ve Bursa ve Muğla illerinde yüz yüze görüşülerek doldurtulmas1 sağlanmış ve toplam 1324 katılımcıya ulaşılmıştır.

Araştırmaya katılan katılımcılara demografik bilgileri almaya yönelik sorulan soruların bulunduğu bölümün sonunda 'Daha önce hiç internet üzerinden yemek siparişi verdiniz mi? (yemeksepeti.com vb. ) ' sorusu yöneltilmiştir. Soruya 'evet' cevabı veren kat1lımcılardan anketi cevaplamaya devam etmeleri istenmiş, 'hayır' cevab1 veren katılımcilardan ise anketi sonlandırmaları istenmiştir. Bu doğrultuda ulaşılan 1324 katılımcıdan 74 kişi daha önce hiç internet üzerinden yemek siparişi vermediğini belirterek anketi cevaplamayı sonlandırmıştır. Araştırmaya katılan 1268 katılımcının doldurduğu anket formlarından 79 tanesi eksik ve/veya hatalı doldurulduğu saptandığı için değerlendirmeye alınmamıştır. Sonuç olarak 1189 adet anket formu değerlendirmeye alınmış ve analizlere dahil edilmiştir.

Çalışma verileri değerlendirilirken tanımlayıcı istatistiksel metotların yanı sıra normal dağılımın incelenmesi için Kolmogorov - Smirnov dağ 11 ım testi kullanılmıştır. Kolmogorov - Smirnov (K-S) testi sonucu verilerin normal dağılım göstermediği saptandığından, veri analizlerinde parametrik olmayan testler kullanılmıştır.

Gerçekleştiren literatür taraması ile birlikte geçmişte yapılmış olan çalışmalar ve başvurulan uzman görüşleri sonrasında araştırma hipotezleri oluşturulmuştur.

Araştırma modeline göre oluşturulan araştırma hipotezleri şu şekildedir:

$\checkmark$ H1a: e-alışveriş kalitesinin algılanan kullanım kolaylığ 1 üzerinde pozitif bir etkisi vardır.

$\checkmark$ H1b: e-alışveriş kalitesinin algılanan kullanışlılık üzerinde pozitif bir etkisi vardır.

$\checkmark$ H2a: Tüketiciler tarafından alg1lanan kullanım kolaylığının algılanan kullanışlılık üzerinde pozitif bir etkisi vardır.

$\checkmark \quad$ H2b: Tüketiciler tarafindan algılanan kullanım kolaylığının algılanan kullanışlılık üzerinde pozitif bir etkisi vardır.

$\checkmark$ H3a: Tüketiciler tarafından algılanan kullanışl1lık boyutunun kullanıma dönük tutum üzerinde pozitif bir etkisi vardır.

$\checkmark$ H3b: Tüketiciler tarafından algılanan kullanışlılık boyutunun kullanıma dönük niyet üzerinde pozitif bir etkisi vardır.

$\checkmark$ H4: Kullanıma yönelik tutumun kullanıma dönük niyet üzerinde pozitif bir etkisi vardır.

$\checkmark$ H5: Öznel normların kullanıma dönük niyet üzerinde pozitif bir etkisi vardır.

$\checkmark$ H6: Kullanıma dönük niyetin gerçek sistem kullanımı üzerinde pozitif bir etkisi vardır.

\section{BULGULAR ve DEĞERLENDİRME}

Tablo 1'de de görüldüğü üzere, katılımcıların \%43,9'u 11-15 y11 aras1, \%33,1'i 6-10 y1l aras1, $\% 17,2$ 'si 16-20 yıl aras1, \%3,3'ü 1-5 y1l aras1 ve $\% 2,4$ 'ü 21 y1lı aşkın süredir interneti aktif bir biçimde kullandıkları, 98,7'sinin interneti günde birkaç kereden fazla kullandığı ve \%86,'sinin internete bağlanırken en çok akıllı telefonlarından yararlandıkları belirlenmiştir.

Tablo 2.Katılımcıların Demografik Özellikleri

\begin{tabular}{|l|l|l|l|}
\hline Cinsiyet & Sıklık & Yüzde & $\begin{array}{l}\text { Kümülatif } \\
\text { toplam }\end{array}$ \\
\hline Kadın & & & 49,7 \\
\hline Erkek & 591 & 49,7 & 100,0 \\
\hline TOPLAM & 598 & 50,3 & \\
\cline { 4 - 5 } & $\mathbf{1 1 8 9}$ & $\mathbf{1 0 0 , 0}$ & \\
\hline
\end{tabular}




\begin{tabular}{|c|c|c|c|}
\hline \multicolumn{4}{|l|}{ Yaş Aralığı } \\
\hline $19-28$ & \multirow{5}{*}{$\begin{array}{l}442 \\
455 \\
211 \\
70 \\
11\end{array}$} & \multirow{5}{*}{$\begin{array}{l}37,2 \\
38,3 \\
17,7 \\
5,9 \\
, 9\end{array}$} & \multirow{5}{*}{$\begin{array}{l}37,2 \\
75,4 \\
93,2 \\
99,1 \\
100,0\end{array}$} \\
\hline $29-38$ & & & \\
\hline $39-48$ & & & \\
\hline $49-58$ & & & \\
\hline $59-68$ & & & \\
\hline TOPLAM & 1189 & 100,0 & \\
\hline \multicolumn{4}{|l|}{ Eğitim durumu } \\
\hline İlkokul/Ortaokul/Lise & \multirow{5}{*}{$\begin{array}{l}\mathbf{1 0 9} \\
443 \\
559 \\
76 \\
\mathbf{1 1 8 9} \\
\end{array}$} & \multirow{5}{*}{$\begin{array}{l}\mathbf{9 , 3} \\
37,3 \\
47,0 \\
6,4 \\
\mathbf{1 0 0 , 0}\end{array}$} & \multirow{5}{*}{$\begin{array}{l}\mathbf{9 , 8} \\
46,6 \\
93,6 \\
100,0 \\
\end{array}$} \\
\hline Ön Lisans & & & \\
\hline Lisans & & & \\
\hline Yüksek Lisans/Doktora & & & \\
\hline TOPLAM & & & \\
\hline \multicolumn{4}{|l|}{ Meslek } \\
\hline Adalet ve Güvenlik Sektörü Çalışanı & \multirow{13}{*}{$\begin{array}{l}18 \\
114 \\
144 \\
80 \\
63 \\
75 \\
150 \\
98 \\
142 \\
259 \\
46 \\
1189\end{array}$} & \multirow{13}{*}{\begin{tabular}{|l|}
1,5 \\
9,6 \\
12,1 \\
6,7 \\
5,3 \\
6,3 \\
12,6 \\
8,2 \\
11,9 \\
21,8 \\
3,9 \\
100,0 \\
\end{tabular}} & \multirow{12}{*}{\begin{tabular}{|l}
1,5 \\
11,1 \\
23,2 \\
29,9 \\
35,2 \\
41,5 \\
54,2 \\
62,4 \\
74,3 \\
96,1 \\
100,0 \\
\end{tabular}} \\
\hline Eğitim Sektörü Çalışanı & & & \\
\hline Finans ve Bankacılık Sektörü Çalışanı & & & \\
\hline Memur & & & \\
\hline Mühendis & & & \\
\hline Sağlık ve Sosyal Hizmetler Çalışanı & & & \\
\hline Ticaret (Satış ve Pazarlama) & & & \\
\hline $\begin{array}{l}\text { Turizm, Konaklama, Yiyecek-İçecek Hizmetleri } \\
\text { Çalışanı }\end{array}$ & & & \\
\hline Ögrenci & & & \\
\hline Ücretli çalışan/İşçi & & & \\
\hline Diğer (ișsiz/çalışmıyor/emekli/ev hanımı) & & & \\
\hline TOPLAM & & & \\
\hline \multicolumn{2}{|l|}{ Medeni durum } & & \\
\hline Evli & \multirow{3}{*}{$\begin{array}{l}533 \\
656 \\
1189 \\
\end{array}$} & \multirow{4}{*}{$\begin{array}{l}44,8 \\
55,2 \\
100,0 \\
\end{array}$} & 44,8 \\
\hline Bekar & & & \multirow{2}{*}{$\begin{array}{l}44,0 \\
100,0\end{array}$} \\
\hline TOPLAM & & & \\
\hline \multicolumn{3}{|l|}{ Çocuk sahipliği } & \\
\hline Evet & \multirow{3}{*}{$\begin{array}{l}375 \\
813 \\
1188 \\
\end{array}$} & \multirow{3}{*}{$\begin{array}{l}31,5 \\
68,5 \\
100,0 \\
\end{array}$} & 31,5 \\
\hline Hayır & & & 68,5 \\
\hline TOPLAM & & & 100,0 \\
\hline \multicolumn{4}{|l|}{ Çocuk Sayısı } \\
\hline 1 & \multirow{4}{*}{$\begin{array}{l}263 \\
112 \\
14 \\
1\end{array}$} & 67,4 & 67,4 \\
\hline 2 & & 28,7 & 96,2 \\
\hline 3 & & 3,6 & 99,7 \\
\hline 4 & & ,3 & 100,0 \\
\hline TOPLAM & 390 & 100,0 & \\
\hline Yasadığınız Mesken & & & \\
\hline Müstakil ev & 147 & & 12,4 \\
\hline Apartman dairesi & 858 & 72,2 & 84,5 \\
\hline Yurt/lojman & 184 & 15,5 & 100,0 \\
\hline TOPLAM & 1189 & 100,0 & \\
\hline Gelir Durumunuz & & & \\
\hline 2000 TL ve alt1 & 37 & 3,1 & 3,1 \\
\hline $2001-4000$ & 271 & 22,8 & 25,9 \\
\hline $4001-6000$ & 732 & 61,6 & 87,5 \\
\hline 6001TL ve üstü & 149 & 12,5 & 100,0 \\
\hline TOPLAM & 1189 & 100,0 & \\
\hline
\end{tabular}


Ankette katılan internet üzerinden yemek siparişi veren 1189 katılımcının \% 73,3'ü ayda ortalama 15 arasında sipariş verirken, \%25,2'si ortalama 6-10 sipariş ve $\% 1,1$ 'i ortalana 11 ve üstü sayıda sipariş vermektedir. Ayrıca katılımciların \%23,0'ü internet üzerinden yemek siparişi verirken tüm kanallardan yararlandığını belirtmiştir. \%25,2'si daha çok web ve mobil cihaz uygulamaları üzerinden, \%18,4'ü ise mobil internet ve mobil cihaz uygulamaları üzerinden sipariş vermektedirler. Katılımcıların internet üzerinden yemek siparişi verirken en az tercih ettikleri kanal ise sadece mobil cihaz uygulamaları (android, ios vb.) olduğu saptanmıştır.

Yemeksepeti 2018 Lezzet Almanağında yer alan bilgilere göre ise yemeksepeti.com üzerinden verilen yemek siparişlerinin \%70'lik kısmı mobil cihaz uygulamaları aracılığıyla verilmektedir. $\mathrm{Bu}$ noktada yemeksepeti.com verileri ile araştırma verileri birbirine uyumluluk göstermemektedir. Katılımcıların internet üzerinden yemek siparişi verirken daha çok tercih ettikleri yemek türleri arasında ilk 5 sirada yer alan yemek türleri sırasıyla şu şekildedir; Pizza \& İtalyan Mutfağı, Burger, Döner, Kebap \& Türk Mutfağı, Pide.

Yemeksepeti 2018 Lezzet Almağında yer alan bilgilere göre ise yılın sipariş lideri burger olmuştur. 2017 yılında listesinde 5. Sirasında yer alan döner, 2018 yılında sipariş sayısını \%70 artırarak listenin ikinci sırasına yerleşmiştir. Lahmacun bir önceki yıla göre bir basamak gerileyerek 3. sırada yer almıştır. Yemeksepeti kullanıc1ları bir yıl boyunca 16 milyon lahmacun yemiştir. Yemeksepeti.com verileri ile araştırma verilerinin sonuçları karşılaştırıldığında kullanıcılar tarafindan en çok tercih edilen yemek çeşitleri bilgileri benzer bir şekilde sıralandiğı görülmektedir. Araştırma sonuçlarına göre katılımcıların internet üzerinden yemek siparişi verirken en az tercih ettikleri yemek türleri arasında son beş sırada yer alan yemek türleri sırasıyla şu şekildedir; Dünya Mutfağı, Kokoreç, Kahve, Dondurma, Japon Mutfağı.

Yemeksepeti 2018 Lezzet Almanağında yer alan bilgilere göre ise Türk insanının vazgeçilmezi olan kahve 2018'de atağa geçerek siparişlerini tam 2 kat arttırmıştır. En çok sevilen kahve çeşidi ise latte olmuştur. Yemeksepeti.com verileri ile araştırma verilerinin sonuçları karşılaştırıldığında kahvenin 18. sirada olduğu görülmektedir.

Genişletilmiş teknoloji kabul modeli ölçeği faktör yapısını ortaya koymak için gerçekleştirilen faktör analizi sonucunda toplam varyans $1 \% 63,42$ olan 6 faktör bulunmuştur.

\section{Tablo 3. Genişletilmiş Teknoloji Kabul Modeli Ölçeği Faktör Yapısı}

\begin{tabular}{|c|c|c|c|c|}
\hline Boyut & Madde & $\begin{array}{l}\text { Faktör } \\
\text { Yükü }\end{array}$ & Varyans & $\begin{array}{l}\text { Cronbach's } \\
\text { Alpha }\end{array}$ \\
\hline \multirow{8}{*}{$\begin{array}{l}\text { Algılanan } \\
\text { kullanışl1l1k } \\
\text { (fayda) }\end{array}$} & $\begin{array}{l}\text { İnternet üzerinden hizmet veren yemek sipariş siteleri farklı } \\
\text { ödeme seçenekleri ile ödeme yapılmasına imkan sağlar. }\end{array}$ &, 745 & \multirow{8}{*}{32,716} & \multirow{8}{*}{, 870} \\
\hline & $\begin{array}{l}\text { İnternet üzerinden hizmet veren yemek sipariş siteleri zaman } \\
\text { tasarrufu sağlar. }\end{array}$ &, 745 & & \\
\hline & $\begin{array}{l}\text { İnternet üzerinden hizmet veren yemek sipariş siteleri tek } \\
\text { işlemde farklı işletmelerden sipariş vermeye imkan sağlar. }\end{array}$ & ,649 & & \\
\hline & $\begin{array}{l}\text { İnternet üzerinden hizmet veren yemek sipariş siteleri } \\
\text { ürünleri/hizmetleri karşılaştırabilme imkanı sağlar. }\end{array}$ &, 557 & & \\
\hline & $\begin{array}{l}\text { İnternet üzerinden hizmet veren yemek sipariş sitelerinden } \\
\text { verilen siparişler hızlı bir şekilde teslim edilir. }\end{array}$ &, 591 & & \\
\hline & $\begin{array}{l}\text { İnternet üzerinden hizmet veren yemek sipariş sitelerini } \\
\text { kullanmayı öğrenmek kolaydır. }\end{array}$ &, 565 & & \\
\hline & $\begin{array}{l}\text { İnternet üzerinden hizmet veren yemek sipariş siteleri ulaşım } \\
\text { masraflarını ortadan kaldırır. }\end{array}$ & ,606 & & \\
\hline & $\begin{array}{l}\text { İnternet üzerinden hizmet veren yemek sipariş sitelerini } \\
\text { kullanmak istediğim gıdalara kolayca ulaşmamı sağlar. }\end{array}$ & ,546 & & \\
\hline
\end{tabular}




\begin{tabular}{|c|c|c|c|c|}
\hline & $\begin{array}{l}\text { İnternet üzerinden hizmet veren yemek sipariş sitelerinde } \\
\text { ihtiyacım olan bilgiye erişmek kolaydır. }\end{array}$ &, 522 & & \\
\hline \multirow{3}{*}{$\begin{array}{l}\text { Algilanan } \\
\text { kullanım } \\
\text { kolaylığı }\end{array}$} & $\begin{array}{l}\text { İnternet üzerinden hizmet veren yemek sipariş sitelerinde } \\
\text { etkileşim açıktır. }\end{array}$ &, 838 & \multirow{3}{*}{6,569} & \multirow{3}{*}{, 836} \\
\hline & $\begin{array}{l}\text { İnternet üzerinden hizmet veren yemek sipariş sitelerinde } \\
\text { etkileşim anlaşlırdır. }\end{array}$ &, 813 & & \\
\hline & $\begin{array}{l}\text { İnternet üzerinden hizmet veren yemek sipariş siteleri } \\
\text { aracılığıyla vermiş olduğum bir siparişi iptal etmek kolaydır. }\end{array}$ & ,759 & & \\
\hline \multirow{3}{*}{$\begin{array}{l}\text { Davranışa } \\
\text { dönük tutum }\end{array}$} & $\begin{array}{l}\text { İnternet üzerinden hizmet veren yemek sipariş sitelerini } \\
\text { kullanmak akılcıdır. }\end{array}$ &, 635 & \multirow{3}{*}{5,440} & \multirow{3}{*}{,477 } \\
\hline & İnternet üzerinden hizmet veren yemek sipariş siteleri önemlidir. &, 547 & & \\
\hline & $\begin{array}{l}\text { İnternet üzerinden hizmet veren yemek sipariş siteleri } \\
\text { aracılı̆̆ıyla yemek sipariş etmek karlıdır. }\end{array}$ &, 582 & & \\
\hline \multirow{2}{*}{$\begin{array}{l}\text { Davranışa } \\
\text { dönük niyet }\end{array}$} & $\begin{array}{l}\text { Bundan sonraki ilk paket yemek servisi siparişimde, internet } \\
\text { üzerinden hizmet veren yemek sipariş sitelerini kullanmayı } \\
\text { düşünüyorum. }\end{array}$ & ,927 & \multirow{2}{*}{6,190} & \multirow{2}{*}{, 875} \\
\hline & $\begin{array}{l}\text { Bundan sonraki tüm paket yemek servisi siparişlerimde, internet } \\
\text { üzerinden hizmet veren yemek sipariş sitelerini kullanmayı } \\
\text { düşünüyorum. }\end{array}$ & ,915 & & \\
\hline \multirow{3}{*}{$\begin{array}{l}\text { Öznel } \\
\text { Normlar }\end{array}$} & $\begin{array}{l}\text { Arkadaş çevrem internet üzerinden hizmet veren yemek sipariş } \\
\text { sitelerini kullanmama olumlu bakar. }\end{array}$ & ,956 & \multirow{3}{*}{8,001} & \multirow{3}{*}{,886 } \\
\hline & $\begin{array}{l}\text { Yakın çevrem internet üzerinden hizmet veren yemek sipariş } \\
\text { sitelerini kullanmama olumlu bakar. }\end{array}$ & ,940 & & \\
\hline & $\begin{array}{l}\text { Görüşlerine değer verdiğim insanlar internet üzerinden hizmet } \\
\text { veren yemek sipariş sitelerini kullanmamı destekler. }\end{array}$ &, 843 & & \\
\hline \multirow{4}{*}{$\begin{array}{l}\text { Gerçek } \\
\text { sistem } \\
\text { kullanımı }\end{array}$} & $\begin{array}{l}\text { Paket yemek siparişlerimde internet üzerinden yemek sipariş } \\
\text { sitelerini kullanmak siparişlerimi kolay bir şekilde veririm. }\end{array}$ &,- 730 & \multirow{4}{*}{4,505} & \multirow{4}{*}{,696 } \\
\hline & $\begin{array}{l}\text { İnternet üzerinden hizmet veren yemek sipariş sitelerini } \\
\text { kullanmak avantajlıdır. }\end{array}$ &,- 671 & & \\
\hline & $\begin{array}{l}\text { İnternet üzerinden hizmet veren yemek sipariş sitelerini } \\
\text { kullanmak bana fayda sağlar. }\end{array}$ &,- 663 & & \\
\hline & $\begin{array}{l}\text { S1k sık internet üzerinden hizmet veren yemek sipariş } \\
\text { sitelerinden sipariş veririm. }\end{array}$ &,- 395 & & \\
\hline
\end{tabular}

E-alışveriş kalitesi ölçeği faktör yapısını ortaya koymak için gerçekleştirilen faktör analizi sonucunda toplam varyansı \%70,61 olan 5 faktör bulunmuștur.

Wolfinbarger ve Gilly, (2003) 'de e alışveriş kalitesi deneyiminin boyutlarını belirlemek ve ealıveriş kalitesini ölçmek için geliştirdikleri ölçekte dört ana boyutun (web sitesi tasarımı, taahhütlerin yerine getirilmesi /site güvenilirliği, gizlilik / güvenlik ve müşteri hizmetleri) müşteri kalite ve memnuniyet konusundaki kararlarını, müşteri sadakatini ve web sitesine yönelik tutumlarını güçlü bir şekilde etkilediği saptamışlardır. Ha ve Stoel, (2009) 'da aynı ölçekten yararlanarak gerçekleştirdikleri araştırmada Wolfinbarger ve Gilly, (2003)'den farklı olarak e-alışveriş kalitesinin boyutlarını web sitesi tasarımı, gizlilik / güvenlik, müşteri hizmetleri ve deneyimleme olarak saptamışlardır. 
Tablo 4. E-alışveriş Kalitesi Ölçeği Yapısı

\begin{tabular}{|c|c|c|c|c|}
\hline Boyut & Madde & $\begin{array}{l}\text { Faktör } \\
\text { Yükü }\end{array}$ & Varyans & $\begin{array}{l}\text { Cronbach's } \\
\text { Alpha }\end{array}$ \\
\hline \multirow{4}{*}{$\begin{array}{c}\text { Müşteri } \\
\text { hizmetleri }\end{array}$} & $\begin{array}{l}\text { MH1 - Müşteri hizmetleri çalışanlarının sorularınıza hemen } \\
\text { cevap vermesi }\end{array}$ &, 811 & \multirow{4}{*}{41,933} & \multirow{4}{*}{,925 } \\
\hline & $\begin{array}{l}\text { MH2 - Müşteri hizmetleri çalışanlarının size her zaman } \\
\text { yardımcı olmaya istekli olması }\end{array}$ & ,752 & & \\
\hline & $\begin{array}{l}\text { MH3 - Müşteri hizmetleri çalışanlarının bir sorunla } \\
\text { karşılaştığınızda, sorunu çözme konusunda samimi bir ilgi } \\
\text { göstermeleri }\end{array}$ & ,751 & & \\
\hline & $\begin{array}{l}\text { MH4 - Müşteri hizmetleri çalışanlarının müşterilerin } \\
\text { ihtiyaçlarına cevap verme konusunda hazır ve istekli olması }\end{array}$ & ,719 & & \\
\hline \multirow{3}{*}{ Deneyimleme } & $\begin{array}{l}\text { D1 - İnternet üzerinden hizmet veren yemek sipariş } \\
\text { sitelerinden alışveriş yapmanın heyecan verici olmas1 }\end{array}$ & ,903 & \multirow{3}{*}{9,697} & \multirow{3}{*}{,782 } \\
\hline & $\begin{array}{l}\text { D2 - İnternet üzerinden hizmet veren yemek sipariş sitelerinin } \\
\text { çekici olmas1 }\end{array}$ &, 801 & & \\
\hline & $\begin{array}{l}\text { D3 - İnternet üzerinden hizmet veren yemek sipariş } \\
\text { sitelerinden alışveriş yapmanın eğlenceli olması }\end{array}$ & ,724 & & \\
\hline \multirow{6}{*}{ Güven/Gizlilik } & GG1 - Vaat ve taahhütlerini yerine getirmesi & 829 & \multirow{6}{*}{7,158} & \multirow{6}{*}{,872 } \\
\hline & GG2 - Yapılan alışverişlerde kendini güvende hissetme & ,791 & & \\
\hline & GG3 - İnternet sitesinin güvenilir bir web sitesi olmas1 & ,789 & & \\
\hline & GG4 - Müşterilerinin bilgilerini gizli tutması & ,681 & & \\
\hline & GG5 - Müşterilerinin favori siparişlerini aklında tutması &, 590 & & \\
\hline & $\begin{array}{l}\text { GG6 - Tam olarak ne istiyorsam ona hızlı bir şekilde } \\
\text { ulaşabilmeme imkan sağlaması }\end{array}$ &, 587 & & \\
\hline \multirow{3}{*}{ Özendirme } & OZENDIRME1 - Kullanıcılara özel indirim kampanyalarl & 890 & \multirow{3}{*}{6,704} & \multirow{3}{*}{, 815} \\
\hline & OZENDIRME2 - İndirim kuponlarl, çekilişler & 871 & & \\
\hline & OZENDIRME3 - Hata riskini en aza indirmesi & 800 & & \\
\hline \multirow{5}{*}{ Web Dizaynı } & WD1 - Canlı yardım sağlaması & ,719 & \multirow{5}{*}{5,119} & \multirow{5}{*}{,832 } \\
\hline & WD2 - Kullanıcılar tarafından yapılmış kötü yorumlar & ,591 & & \\
\hline & WD3 - Site görünümü & ,579 & & \\
\hline & WD4 - Gerçek kullanıcı yorumlarına erişebilme & ,560 & & \\
\hline & WD5 - Geri bildirime duyarlı olmaları &, 538 & & \\
\hline
\end{tabular}

$\mathrm{Bu}$ çalışmada e-alışveriş kalitesi ölçeğine ait olan ifadeler Wolfinbarger ve Gilly, (2003) tarafindan geliştirilmiş olan ve Ha ve Stoel, (2009)'da kullanılmış olan e-TailQ ölçeğinden uyarlanmıştır. Elde edilen verilerin analizi aşamasında gerçekleştirilen faktör analizi sonucunda geçmiş çalışmalardan farklı olarak yeni bir boyut elde edilmiştir. Faktör analizi sonuçlarında 'Kullanıcılara özel indirim kampanyaları, İndirim kuponları, çekilişler, Hata riskini en aza indirmesi' önermelerinin tek bir faktör altında toplandığ 1 
görülmüş ve yeni yeni boyut araştırmacı tarafından 'Özendirme' faktörü olarak isimlendirilmiştir.

Yapılan korelasyon analizleri sonucunda, ealışveriş kalitesi ile algılanan kullanışlılık ve kullanım kolaylığı arasındaki ilişki durumuna ait hipotez testlerine ilişkin sonuçlar incelendiğinde; çalışmaya katılanların e-alışveriş kalitesine ait toplam skorları ile algılanan kullanışlılık alt boyutuna ait skorlar arasında istatistiksel olarak anlaml, normal ve pozitif korelasyon olduğu saptanmıştır $(\mathrm{p}<0,05)$.

Çalışmaya katılanların e-alışveriş kalitesine ait toplam skorları ile alt boyutuna ait kullanım kolaylığı alt boyutlarına ait skorlar arasında istatistiksel olarak anlaml, zayıf ve pozitif korelasyon olduğu belirlenmiştir $(p<0,05)$. Buna göre algılanan kullanışlılık ve kullanım kolaylığı, e-alışveriş kalitesine paralel olarak birlikte azalmakta ve birlikte artmaktadır. Bu doğrultuda ealışveriş kalitesinin algılanan kullanım kolaylığı ve algılanan kullanışlılık üzerine pozitif ve anlamlı bir etkisinin olduğu saptanmıştır.

Algılanan kullanım kolaylığı ile algılanan kullanışlılık ve kullanıma dönük tutum arasındaki ilişki durumuna ait hipotez testlerine bakıldığında, çalışmaya katılanların algılanan kullanım kolaylığı alt boyutuna ait toplam skorları ile algilanan kullanışlılık ve kullanıma dönük tutum alt boyutuna ait skorlar arasında istatistiksel olarak anlaml, normal ve pozitif korelasyon olduğu saptanmıştır $(\mathrm{p}<0,05)$. Buna göre algilanan kullanışlılık ve kullanıma dönük tutum, algılanan kullanım kolaylığına bağlı olarak birlikte azalmakta ve birlikte artmaktadır. Bu doğrultuda tüketiciler tarafından algilanan kullanım kolaylığının algılanan kullanışlılık üzerinde pozitif ve anlamlı bir etkisi vardır. Benzer bir şekilde Çetinsöz (2015)'de Teknoloji Kabul Modeli (TKM) kapsamında, yerli turistlerin turistik mal veya hizmetlere yönelik e-satın alma eğilimlerini belirlemek amacıyla gerçekleştirmiş olduğu araştırma sonucunda, algılanan kullanım kolaylığ faktörünün yerli turistlerin e-satın alma tutumlarını anlamlı ve pozitif bir şekilde etkilemekte olduğunu belirlemiştir. Ayrıca, Guritno ve Siringoringo (2013)'de gerçekleştirdikleri araştırmaları sonucunda çevrimiçi havayolu taşımacılığı satın alınmasında, tüketicilerin algıladıkları güven, algılanan fayda ve algılanan kullanım kolaylığının çevrimiçi bilet kullanımına karşı tutumu olumlu bir şekilde etkiledikleri tespit etmişlerdir.

Algılanan kullanışlılık, kullanıma dönük tutum ve kullanıma dönük niyet boyutları arasındaki ilişki durumuna ait hipotez testlerinde ise katılımcıların algılanan kullanışlilık alt boyutuna ait toplam skorları ile algılanan kullanışlılık ve kullanıma dönük niyet alt boyutuna ait skorlar arasında istatistiksel olarak anlaml1, normal ve pozitif bir korelasyon saptanmıştır $(\mathrm{p}<0,05)$. Ayrıca kullanıma dönük tutum ve kullanıma dönük niyet alt boyutuna ait skorlar arasında istatistiksel olarak anlaml, zayif ve pozitif korelasyon saptanmıştır $(\mathrm{p}<0,05)$. Buna göre algılanan kullanışl1lık, kullanıma dönük tutum ve niyete paralel olarak birlikte azalmakta ve birlikte artmaktadır. Kullanıma dönük tutum ve kullanıma dönük niyet de yine birbiri ile bağlı şekilde azaldığ 1 ve arttığ1 görülmüştür. $\mathrm{Bu}$ doğrultuda tüketiciler tarafından algılanan kullanışlılık boyutunun kullanıma dönük tutum üzerinde pozitif ve anlamlı bir etkisi vardır.

Araştırma sonuçlarına benzer bir şekilde Koufaris (2002)'de gerçekleştirdiği çalışmasında, tüketicilerin bir web sitesinden satın alma kararını etkileyen faktörler ve aynı siteden yeniden alışveriş yapma nedenlerini araştırmıştır. Çalışmanın sonuçlarına göre algılanan kullanışlılık faktörünün kullanıma dönük niyet üzerinde yüksek derecede etkiye sahip olduğu saptanmıştır.

Kullanıma dönük tutum ile öznel normlar ve gerçek sistem kullanımı arasındaki ilişki durumuna ait hipotez testlerinde ise çalışmaya katılanların kullanıma dönük niyet alt boyutuna ait skorları ile öznel normal ve gerçek sistem kullanımı alt boyutlarına ait skorlar arasında istatistiksel olarak anlaml, normal ve pozitif korelasyon vardir. $(p<0,05)$ Buna göre öznel normlar ve gerçek sistem kullanımı, kullanıma dönük niyet ile birlikte azalmakta ve birlikte artmaktadır. Bu doğrultuda öznel normların kullanıma dönük niyet üzerinde pozitif ve anlamlı bir etkisi olduğu saptanmıştır.

Benzer bir şekilde Arı ve Yılmaz (2015) üniversite öğrencilerinin çevrimiçi yemek siparişi davranışlarını teknoloji kabul modeliyle araştırdıkları çalışmalarında, Teknoloji Kabul Modeli yardımıyla ortaya koydukları çevrimiçi yemek siparişine ilişkin modelde, algılanan fayda, algılanan kullanım kolaylığının davranışa yönelik tutumu pozitif yönde etkilediği, davranışa yönelik 
tutum ve kişisel normun ise öğrencilerin çevrimiçi yemek siparişi verme sayısını arttırıcı yönde etkilediği sonucuna varmışlardır.

Bununla birlikte Y1lmaz (2015)'de internet üzerinden alışveriş yapan tüketicilerin niyetini etkileyen faktörler için, 1989 yllında Davis tarafindan geliştirilen Teknoloji Kabul Modeli'nden (TKM) yola çıkarak algılanan kullanım kolaylığı, algılanan kullanışlılık, algilanan haz, tutum ve niyetin yanı sira modelde alg1lanan bilgi kalitesi, algilanan sistem kalitesi, alg1lanan hizmet kalitesi, mağaza bilinirliği, güven ve öznel norm değişkenlerine de yer verdikleri ve gerçekleştirdikleri araştırma bulgularına göre öznel norm hariç olmak üzere modelde kullanılan tüm değişkenler arasındaki yol katsayıları anlamlıdır. Çalışmaya göre, öznel norm, tüketicilerin çevrimiçi alışveriş niyetini belirlemede rol oynamamaktadır.

\section{SONUÇ}

$\mathrm{Bu}$ çalışmada çevrimiçi aracı olarak hizmet veren paket yemek sipariş siteleri kullanan tüketicilerin tüketim alışkanlıkları ve sistemi benimseme durumları hakkında bilgiler elde edilmeye çalışılmıştır. Gerçekleştirilen analizler sonucunda;

- e-alışveriş kalitesi ile algılanan kullanışlılık ve algılanan kullanım kolaylığı,

- Algılanan kullanışlılık ile kullanıma dönük tutum ve kullanıma dönük niyet,

- Kullanıma dönük tutum ile kullanıma dönük niyet,

- Kullanıma dönük niyet ile öznel normlar ve gerçek sistem kullanımı

boyutları arasında zayıf ve orta derecelerde pozitif yönlü ilişkiler olduğu görülmüştür. Araştırılan tüm boyutların arasında anlamlı ilişkiler tespit edilebilirken bu ilişkilerin hiçbirinin güçlü oranlarda olmayışı, bu boyutların sadece bir iki faktöre değil çok sayıda değişkene düşük oranlarda bağlılık gösterdiği şeklinde yorumlanabilir. Yapılan ortalama karşılaştırmaları sonucunda medeni halin incelenen boyutlardan hiçbirine anlamlı şekilde etki etmediği görülürken, cinsiyet ve çocuk sahibi olmanın bazı boyutlar üzerinde farklılığa sebep olduğu görülmüştür.

Kadın ve erkek katılımcıların ölçümleri birbiri ile karşılaştırıldığında cinsiyetin öznel normlar üzerinde etkili olduğu görülmüştür. Kadınlar ölçeğin bu boyutunda erkeklere göre ortalamada daha yüksek skor çıkarmışlardır. Aynı şekilde teknoloji kabul modeli genelinde de yine kadınların erkeklere göre ortalamada daha yüksek skor çıkardığı görülmektedir.

Katılımcılarım cevapları ebeveyn olma durumuna göre değerlendirildiğinde ise çocuk sahibi olmanın algılanan kullanım kolaylığ 1 , gerçek sistem kullanımı ve teknoloji kabul modelinin skor ortalamaları üzerinde negatif etkisi olduğu görülmektedir.

Ekonomik durumun hem e-alışveriş kalitesi hem teknoloji kabul modeli ölçeklerinde hem de bu ölçeklerin bazı alt boyutlarında anlamlı şekilde etkili olduğu görülmüştür. Aralarında fark bulunan ikili grup karşılaştırmaları incelendiğinde, elde edilen aylık gelirin yükselmesiyle teknoloji kabul modeli ölçeği ve bu ölçeğe ait algılanan kullanışlılık, algılanan kullanım kolaylığı, gerçek sistem kullanımı, kullanıma dönük tutum ve öznel normlar alt boyutlarında skor ortalamalarının da paralel şekilde artış gösterdiği tespit edilmiştir. Sadece kullanıma dönük niyet boyutunda, gelir seviyesi artarken skor ortalamasının birbirini takip eden artış ve azalışlarla dalgalı bir değişim gösterdiği görülmektedir.

Diğer yandan e-alışveriş kalitesi ve bu ölçeğe ait web dizaynı ile müşteri hizmetleri skor ortalamalarının, bireylerin aylık gelirleri 6000 ve üzerine çıktığında anlamlı şekilde düşüş gösterdiği görülmektedir.

Katılımcıların aylık sipariş sayıları "1-5 arası" ile "6 ve daha fazla" şeklinde 2 grubu ayrıldığında, gruplar arasında hem E-alışveriş kalitesi hem teknoloji kabul modeli ölçeklerine hem de bu ölçeklerin bazı alt boyutlarına ait skor ortalamalarının anlamlı şekilde farklı olduğu görülmüştür. Aralarında fark bulunan ikili grup karşılaştırmaları incelendiğinde, aylık sipariş sayısının daha yüksek olduğu grupta teknoloji kabul modeli ölçeği ve bu ölçeğe ait algılanan kullanım kolaylığı ve gerçek sistem kullanımı skor ortalamalarının da paralel şekilde daha yüksek olduğu saptanmıştır. Buna ilave olarak, e-alışveriş kalitesi ölçeğinde ve bu ölçeğe ait güvenilirlik gizlilik, web dizaynı ve müşteri hizmetleri alt boyutlarında sipariş sayısı arttıkça skor ortalamalarının da yine daha yüksek çıktığı tespit edilmiştir.

Araştırma zaman yetersizliği ve ekonomik sebepler nedeniyle sadece örnek olarak seçilmiş olan paket yemek servis portalına (yemeksepeti.com) üye olan 
ve en az bir kez bu portal aracılığıly paket yemek siparişi veren üyeler üzerinden yürütülmüştür. Anket çalışması çevrimiçi paket yemek servis portallarını kullanan katılımcıların davranışlarının genişletilmiş teknoloji kabul modeli ile e-alışveriş kalitesi ölçeği kapsamında değerlendirilmesi ile sinırlidir.

Yiyecek içecek işletmelerin çevrimiçi paket yemek servis sağlayıcıları ile çalışma nedenlerinin başında işletmenin satış potansiyelini arttırma amacı gelmektedir. Bununla birlikte işletmenin reklam ve tanıtımını yaparak yeni müşteri kazanma, müşteri talep ve beklentilerine karşıllk vermek, rekabet gücünü arttırmak, teknolojik gelişmelere ayak uydurmak, işletmenin imajını güçlendirmek, müşteri ilişkilerini güçlendirmek, çevrimiçi paket servis altyapısının maliyetli olması nedeniyle çevrimiçi aracı kullanmak da işletmelerin çevrimiçi aracı kullanma nedenleri arasındadır. Bu çalışma sadece internetten yemek sipariş sunan yemeksepeti.com sitesi aracılığıyla paket yemek hizmeti satın alan tüketiciler üzerinden yürütülmüş̧ür. Gelecekte gerçekleştirilmesi planlanan çalışmalarda çevrimiçi yemek sipariş sektöründe faaliyet gösteren diğer çevrimiçi aracı işletmeler ve bu araci siteleri kullanan yiyecek içecek işletmeleri üzerinden benzer bir çalışma yürütülerek karşılaştırma imkanı sağlanabilir.

Elektronik ticaretin Türkiye'de gün geçtikçe artan hacmine rağmen, bu konu hakkında yapılmış olan çalışmaların ve verilerin azlığı oldukça dikkat çekmektedir. $\mathrm{Bu}$ durum, firma ve işletmelerin elektronik ticaret alanında doğru kararlar alabilmesi ve akılc1 yatırımlar yapabilmesi açısından önemli bir dezavantaj olarak karşımıza çıkmaktadır. Literatürde hakkında oldukça az sayıda bulunan yiyecek-içecek işletmelerinde eticaret ve yiyecek-içecek işletmelerinde çevrimiçi aracı kullanımı alanında yapılan bu çalışma sonuçlarının işletmelere, ilgili literatüre ve bu alanda ilerleyen yıllarda yapılacak çalışmalara kaynak olabileceği düşünülmektedir.

\section{KAYNAKÇA}

Akça, Y., \& Özer, G. (2012). Teknoloji Kabul Modeli'nin Kuramsal Kaynak Planlaması Uygulamalarında Kullanılmasi. Business and Economics Research Journal, 3(2), 79-96.

Alagoz, S. M., \& Hekimoglu, H. (2012). A study on tam: analysis of customer attitudes in online food ordering system. Procedia - Social and Behavioral Sciences, 62(2012), 1138 - 1143.

Algür, S., \& Cengiz, F. (2011). Türk Tüketicilere Göre Online (çevrimiçi) Alışverişin Riskleri ve Yararlar1. Journal of Yasar University, 22(6), 3666-3680.

Ar1, E., \& Y1lmaz, V. (2015). Üniversite Öğrencilerinin Online Yemek Siparişi Davranışlarının Teknoloji Kabul Modeliyle Araştırılması. Uluslararası Alanya Işletme Fakültesi Dergisi, 7(2), 65-84.

Bai, B., Law, R., \& Wen, I. (2008). The impact of website quality on customer satisfaction and purchase intentions: Evidence from Chinese online visitors. International Journal of Hospitality Management(27), s. 391-402.

BKM. (2018). Mektupla / Telefonla Sipariş ve ETicaret Isslemleri Raporu. Bankalararası Kart Merkezi. 03 12, 2019 tarihinde https://bkm.com.tr adresinden alınd 1

Bozdoğan, M. (2012). Turizm İşletmelerinde ETicaret: Yemeksepeti.com Üzerinde Satış Yapan Yiyecek-İçecek İşletmelerinde Bir İnceleme: Konya İli Örneği. Tokat: Gaziosmanpaşa Üniversitesi Sosyal Bilimler Enstitüsü, Turizm İşletmeciliği ve Otelcilik Ana Bilim Dalı, Yayınlanmamış Yüksek Lisans Tezi.

Canpolat, Ö. (2001). E-Ticaret ve Türkiye'deki Gelişmeler. Ankara. 05 19, 2019 tarihinde http://my.beykoz.edu.tr/serkang/files/2010/12/eticaret-ve-Turkiye1.pdf adresinden alınd 1

Chen, L.-D., \& Tan, J. (2004). Technology adaptation in e-commerce: Key determinants of virtual Stores Acceptance. European Management Journal, 22(1), 74-86.

Chen, Y.-H., Hsu, I.-C., \& Lin, C.-C. (2010). Website attributes that increase consumer purchase intention: A conjoint analysis. Journal of Business Research, 63(2010), 1007-1014.

Constantinides, E. (2004). Influencing the online consumer's behavior: the Web experience. Internet Research, 14(2), 111-126.

Çetinsöz, B. C. (2015). YERLİ TURISSTLERİN ESATIN ALMA EĞILIMLERININ TEKNOLOJI KABUL MODELINDE ANALIZİ (TKM). Elektronik Sosyal Bilimler Dergisi, 14(53), 242258. 
Dahlberg, T., Mallat, N., \& Oorni, A. (2003). Trust enhanced technology acceptance model-consumer acceptance of mobile payment solutions: Tentative evidence. Proceedings of the CIC roundtable 2003. $12 \quad 24, \quad 2018 \quad$ tarihinde https://www.researchgate.net/publication/2679340 58 adresinden alınd 1

Davis, F. D. (1989). Perceived Usefulness, Perceived Ease of Use and User Acceptance of İnformation Technology. MIS Quarterly, 13(3), 319-340.

Davis, F., Bagozzi, R., \& Warshaw, P. (1989). User Acceptance of Computer Technology: A Comparison of Two Theoretical Models. Management Science, 8(35), 982-1003.

Dou, W., \& Chou, D. C. (2002). A structural analysis of business-to-business digital markets. Industrial Marketing Management(31), s. 165-176.

Enginkaya, E. (2006). Elektronik Perakendecilik ve Elektronik Alışveriş. Ege Academic Review, 1016.

Erbaşlar, G., \& Dokur, Ş. (2012). elektronik ticaret, e-ticaret. Ankara: Nobel Yayın.

Erçetin, C. (2015). Elektronik Ticarette Tüketicilerin Satın Alma Davranış ve Tercihlerini Etkileyen Unsurlar: E-Ticaret Siteleri Üzerine Bir Çalışma. İstanbul: T.C. Doğuş Üniversitesi Sosyal Bilimler Enstitüsü, İşletme Anabilim Dalı, Bitirme Tezi.

Fishbein, M., \& Ajzen, I. (1975). Belief, Attitude, Intention and Behavior: An Introduction to Tehory and Research. Boston: Addison-Wesley.

Flavian, C., Guinaliu, M., \& Gurrea, R. (2006). The role played by perceived usability, satisfaction and consumer trust on website loyalty. Information \& Management, 43, 1-14.

Guritno, S., \& Siringoringo, H. (2013). Perceived Usefulness, Ease of Use, and Attitude Towards Online Shopping Usefulness Towards Online Airlines Ticket Purchase. Procedia Social and Behavioral Sciences(81), 212-216.

Ha, S., \& Stoel, L. (2009). Consumer e-shopping acceptance: Antecedents in a technology acceptance model. Journal of Business Research, $62,565-571$.

Hansen, T., Jensen, J., \& Solgaard, H. (2004). Predicting Online Grocery Buying Intention: A Comparison of The Theory of Reasoned Action and The Theory of Planned Behavior. International Journal of Information Management, 24(6), 539-550.

Hong, I. B., \& Cho, H. (2011). The impact of consumer trust on attitudinal loyalty and purchase intentions in B2C e-marketplaces: Intermediary trust vs. seller trust. International Journal of Information Management, 31(2011), 469-479.

Kemp, S. (2016, Ocak 27). We are social. 03 25, 2016 tarihinde we are social web sitesi: http://wearesocial.com/special-reports/digital-in2016 adresinden alınd 1

Kimes, S. E. (2011a). The Current State of Online Food Ordering in the U.S. Restaurant Industry. Center for Hospitality Research Publications, 11(17), 6-18.

Kimes, S. E. (2011b). Customer Perceptions of Electronic Food Ordering. Cornell Hospitality Report, 11(10), 4-18.

Kimes, S. E., \& Laqué, P. F. (2011). Online, Mobile, and Text Food Ordering in the Restaurant Industry. Cornell Hospitality Report, 11(7), 1-20.

Lai, V., \& Li, H. (2005). Technology Acceptance Model for Internet banking: an invariance analysis. Information \& Management, 42(2), 373-386.

Lam, T., Cho, V., \& Qu, H. (2007). A Study of Hotel Employee Behavioral Intentions Towards Adoption of Information Technology. International Journal of Hospitality Management(26), 49-65.

Liang, A., \& Lim, W. M. (2011). Exploring The Online Buying Behavior of Spacialty Food Shoppers. International Journal of Hospitality Management(30), 855-865.

Pavlou, P. A. (2003). Consumer acceptance of electronic commerce: Integrating trust and risk with the technology acceptance model. International Journal of Electronic Commerce, 7(3), 101-134.

Shim, S., Eastlick, M., Lotz, S., \& Warrington, P. (2001). An Online Purchase Intentions Model: The role of Intention to Search. Journal of Retailing(77), 397-416.

Suh, B., \& Han, I. (2002). Effect of Trust on Customer Acceptance of Internet Banking. Electronic Commerce Research and Applications, 1, 247-263. 
Taylor, S., \& Todd, P. A. (1995). Understanding Information Technology Usage: A Test of Competing Models. Information Systems Research, 6(2), 144- 176.

Tekinay, A. (2000). E-Tailing Rüzgarı. Capital(May1s), 124-126.

Tiryaki, B. (2008). E-Tüketici ve Mesafeli Sözleşmelerde Tüketicinin Korunması. XIII. Türkiye'de Internet Konferansı Bildirileri, (s. 9196). Ankara.

Tomaş, M. (2014). Paket Servis Müşterilerinin Sipariş Vermede E-Aracı Kullanma Nedenleri Üzerine Keşifsel Bir Araştırma: yemeksepeti.com Örneği. Internet Uygulamaları ve Yönetimi, 5(2), 29-41.

TUIK. (2018). Hanehalkı Bilişim Teknolojileri (BT) Kullanım Araştırması, 2018. Hanehalkı Bilişim Teknolojileri (BT) Kullanım Araştırması, 2018. 04 12, 2019 tarihinde www.tuik.gov.tr: http://www.tuik.gov.tr/PreHaberBultenleri.do?id=2 7819 adresinden alındı

Turan, A. H. (2008). İnternet Alışverişi Tüketici Davranışını Belirleyen Etmenler: Geliştirilmiş Teknoloji Kabul Modeli (E-TAM) ile Bir Model Önerisi. Ç. Üniversitesi (Dü.), X. Akademik Bilişim Konferansı içinde, (s. 723-731). Çanakkale.

Turhan, A. H., \& Özgen, F. B. (2009). Türkiye'de e-Beyanname Sisteminin Benimsenmesi: Geliştirilmiş Teknoloji Kabul Modeli ile Ampirik Bir Çalışma. Doğuş Üniveristesi Dergisi, 1(10), 134-147.

TUSİAD. (2019). E-Ticaretin Gelişimi, Sinırların Aşılması ve Yeni Normlar. TUSIAAD.

Vijayasarathy, L. R. (2004). Predicting consumer intentions to use on-line shopping: the case for an augmented technology acceptance model. Information \& Management, 41(6), s. 747-762.
WB. (2016, 04 01). worldbank.org. worldbank.org web sitesi: http://data.worldbank.org/indicator/SP.POP.TOTL adresinden alınd 1

wearesocial.com.

https://digitalreport.wearesocial.com/. 5 17, 2019 tarihinde https://digitalreport.wearesocial.com/ adresinden alınd 1

Wolfinbarger, M., \& Gilly, M. C. (2003). eTailQ: dimensiolionalizing, measuring and predciting etail quality. Journal of Retailing, 2003(79), 183-198.

WTO. (tarih yok). 04 14, 2016 tarihinde World Trade Organization: https://www.wto.org/ adresinden alınd 1

Wu, J.-H., \& Wang, S.-C. (2005). What Drives Mobile Commerce? An Empirical Evaluation Of The Revised Technology Acceptance Model. Information \& Management, 42(5), 719-729.

yemeksepeti.com. (2016). https://blog.yemeksepeti.com/. $12 \quad 17,2018$ tarihinde

https://blog.yemeksepeti.com/index.php/2016/12/0 9/yemeksepeti-vale-hizmeti-ile-artik-hicbir-lezzetulasilmaz-degil/ adresinden alınd 1

yemeksepeti.com. (2019). 2018 Lezzet Almană̆g. İstanbul: yemeksepeti.com. 05 14, 2019 tarihinde https://blog.yemeksepeti.com/index.php/2019/01/2 4/yemeksepetinden-2018-lezzet-almanagi/ adresinden alınd 1

Y1lmaz, C. (2015). İnternet Üzerinden Alışveriş Niyetini Etkileyen Faktörlerin Genişletilmiş Teknoloji Kabul Modeli Kullanarak İncelenmesi Ve Bir Model Önerisi. Celal Bayar Üniversitesi Iktisadi ve İdari Bilimler Fakültesi Dergisi, 22(2), $355-384$. 